\title{
KOMUNIKASI POLITIK MUBALLIG DI KOTA PALU (Studi Kampanye Pemilihan Presiden dan Wakil Presiden 2014)
}

\author{
Syamsuri \\ Institut Agama Islam Negeri (LAIN) Palu \\ syamsuri@iainpalu.ac.id
}

\begin{abstract}
This study revealed the phenomenon of mubaligh involvement in political events of the Election of President and Vice President of the Republic of Indonesia, the period from 2014 to 2019. The study took place during the campaign, from the date of June 4, 2014 to July 5, 2014. Through a phenomenology approach, mubaligh in Palu attempted to negotiate among stakeholders power of political parties, relate consolidation among voters, and the description of imaging as political messages to Muslim audiences. Various missionary activities always were used to convey the vision and mission of Candidates for President and Vice President whom they supported. The largest Muslim women organization in Palu, Alkhairaat, together with mubaligh, participated in the political contest
\end{abstract}

Keywords: negotiation, consolidation, imaging

\begin{abstract}
Abstrak
Penelitian ini mengungkapkan fenomena keterlibatan muballig dalam peristiwa politik. Pemiliban Umum Presiden dan Wakil Presiden Republik Indonesia, periode 2014-2019. Penelitian ini berlangsung pada masa kampanye, dari tanggal 4 Juni 2014 sampai 5 Juli 2014. Melalui pendekatan fenomenologi, Muballig di Kota Palu berupaya melakukan negosiasi di kalangan pemangku kekuasaan partai politik, merelasikan konsolidasi di kalangan pemilih, dan uraian pencitraan sebagai pesan-pesan politik kepada kbalayak umat Islam. Berbagai kegiatan dakwah selalu dimanfaatkan untuk menyampaikan visi dan misi Calon Presiden dan Wakil Presiden yang didukungnya.Keterlibatan muballig dalam kontestasi politik, turut serta dimeriabkan oleh organisasi perempuan terbesar di Kota Palu, yaitu Wanita Islam Alkhairaat.
\end{abstract}

Kata Kunci: negosiasi, konsolidasi, pencitraan. 


\section{Pendahuluan}

Dinamika politik pada setiap peristiwa pesta demokrasi selalu mengoptimalkan penggarapan seluruh unsur-unsur potensial di basis-basis pemilih. Sentimen emosional keagamaan dipandang oleh kandidat yang bertarung pada pesta demokrasi sebagai sarana untuk mengokohkan kekuatan peraihan suara pada saat pemilihan. Muballig sebagai tokoh informal dan informatif umat Islam selalu diikutsertakan dalam tim-tim kampanye untuk mengukuhkan kekuatan politik bagi kandidat tertentu.

Semangat aktivitas keagamaan umat Islam tidak luput dari incaran politisi sebagai sebuah komoditas politik dalam kampanye Pemilihan Presiden dan Wakil Presiden Periode 2014-2019.Muballig yang dianggap representasi masyarakat muslim segera dilibatkan dalam proses pemenangan even demokrasi lima tahunan. Ada muballig yang masuk sebagai anggota timsukses secara resmi dan ada yang dipolakan pada acara-acara tertentu saja (the bidden team). Muballig yang sudah menjadi anggota partai politik, wajib mengikuti keputusan pimpinan partai untuk mengkampanyekan pasangan calon yang didukungnya. Sedangkan muballig yang pemimpin informal selalu didekati oleh partai pengusung untuk didaftar sebagai anggota timsukses.

Kota Palu adalah ibukota Provinsi Sulawesi Tengah, tidak pernah terlepas dari keriuhan dampak peta politik nasional. Keikutsertaan muballig dalam kegiatan kampanye pemilihan kepala negara dimaknai sebagai partsipasi dalam pembangunan nasional. Jaringan komando muballig sudah tertata dari tingkat pusat hingga ke daerah. Para muballig diikutkan dalam pelatihan memahami visi dan misi kandidat dukungannya supaya seiring sejalan dengan anggota tim sukses atau tim kampanye dalam koalisinya.

Pada pemilu 2014, terdapat dua pasangan calon presiden dan calon wakil presiden, yaitu 1) Prabowo Subianto dan Hatta Rajasa, dan 2) Joko Widodo dan H.M. Jusuf Kalla.Kedua pasangan kandidat ini didukung oleh beberapa partai politik. Partai Gerakan Indonesia Raya (Gerindra), Partai Persatuan Pembangunan (PPP), Partai Keadilan Sejahtera (PKS), Partai Bulan Bintang (PBB), dan Partai Golongan Karya (Golkar) mendukung kandidat nomor 1. 
Partai Demokrasi Indonesia Perjuangan (PDIP), Partai Nasional Demokrat (Nasdem), Partai Kebangkitan Bangsa (PKB), Partai Hati Nurani Rakyat (HANURA), dan Partai Keadilan dan Persatuan Indonesia (PKPI) mendukung kandidat nomor 2.

Azyumardi Azra (2014: 6) mengemukakan bahwa dari sudut agama, kedua pasang Calon Presiden dan Calon Wakil Presiden tidak ada bedanya, keempatnya adalah pemeluk Islam. Meski sama-sama muslim, visi keislaman, latar belakang sosial-intelektual, kesetiaan pada doktrin dan ritual Islam, dan kedekatan masing-masing dalam batas tertentu jelas mengandung sejumlah perbedaan. Perbedaanperbedaan itu tentu memengaruhi kecenderungan dan warna politik yang mereka tampilkan, baik pada musim kampaye dan pemungutan suara, maupun dalam masa pemerintahan kalau terpilih sebagai pemenang.

Warna keagamaan kedua pasangan kandidat tidak berpengaruh kepada pilihan muballig di Kota Palu dari latar belakang organisasi. Hubungan antara Nahdlatul Ulama dan Muhammadiyah, menjadi "cair" memandang kedua pasangan ini. Tidak ada fanatisme ideologi keagamaan yang menerpa muballig berkaitan dengan even 9 Juli 2014. Yang mengikat muballig adalah "atas perintah" pimpinan partai. Warna partai sangat "kental" pada polarisasi dukungan muballig. Potret nasional menjadi format di Kota Palu. Ali Ishak Ngabalin, yang menjadi anggota Tim Sukses JK-Wiranto pada pemilihan tahun 1999, namun pada pemilihan kali ini memilih menjadi Tim Sukses Prabowo-Hatta.

Para muballig di Kota Palu yang sudah menjadi aktivis partai, apalagi kalau sudah terpilih menjadi anggota legislatif pada Pemilihan Umum 9 April 2014, harus memperlihatkan loyalitas partai supaya tidak diberi sanksi pemecatan, yang berakibat gugurnya keanggotaan parlemen. Sedangkan muballig anggota partai yang tidak terpilih menjadi anggota parlemen, ternyata memiliki pilihan terbuka untuk mendukung pasangan kandidat tertentu.

Fenomena keterlibatan muballig Kota Palu dalam peristiwa politik pemilihan kepala negara, menambah khasanah cakrawala pemikiran politik Islam sebagai sebuah strategi dakwah.Penelitian di bidang ini memaparkan agenda akademik lokalitas, sehingga 
pembaca selanjutnya dapat memahami konteks politik lokal di Kota Palu. Muballig menjadi agen politik yang bersahaja, karena selalu bersama dengan khalayak umat Islam sebagai massa potensial.

\section{Paradigma Komunikasi Politik}

Komunikasi politik merupakan pengembangan dari ilmu politik. Politik bermakna sebagai upaya mengatur kehidupan dalam sebuah sistem bernegara.Orang-orang yang berada di sebuah negara biasa disebut rakyat atau warganegara - harusmengikuti ketentuan yang sudah diatur dalam konsensus.Cara membuat konsensus sesuai dengan sistem kepemimpinan di suatu negara.Negara yang menganut monarkhi, pembuatan konsensus dibuat oleh penguasa untuk dipatuhi oleh rakyatnya.Sedangkan negara yang menganut sistem demokrasi, konsensus dibuat berdasarkan kesepakatan rakyat. Tidak semua rakyat turut serta membuat konsensus, tapi diwakili oleh beberapa orang sesuai proporsi yang juga diatur konsensus. Konsensus ini kemudian disebut konstitusi.

Ilmu politik berkembang seiring kepentingan warganegara untuk memahami sistem bernegara dan ikut berpartisipasi dalam pembangunan nasional.Orang-orang yang menekuni ilmu politik terus melakukan penelitian dan pengkajian seiring dengan perkembangan negara, baik dalam konstalasi lokal, regional, maupun global.Ilmu politik berfungsi memberikan informasi kepada tentang posisi negara, sehingga warganegara dan penyelanggara negara memiliki kesamaan pandangan terhadap negara.

"Kesamaan" adalah definisi komunikasi.Penggunaan lambang, isyarat, kial, dan gestur dalam kehidupan menjadi cikal bakal kajian ilmu komunikasi.Konstalasi sistem politik yang menggandeng berbagai kepentingan, melahirkan species baru ilmu pengetahuan yaitu komunikasi politik.Komunikasi politik menjadi sarana saling kontrol antara warganegara dengan penyelenggara negara. Warganegara memahami kewajibannya kemudian memperoleh hak dari kewajiban negara terhadap penghuninya.

Beberapa pakar memberi pengertian tentang komunikasi politik. Hafied Cangara (2009:36) mengemukakan, komunikasi politik adalah suatu proses komunikasi yang memiliki implikasi 
atau konsekuensi terhadap aktivitas politik.Susanto (1985:2) mendefinisikan komunikasi politi sebagai komunikasi yang diarahkan kepada pencapaian suatu pengaruh sedemikian rupa, sehingga masalah yang dibahas oleh jenis kegiatan komunikasi ini, dapat mengikat semua warganya melalui suatu sanksi yang ditemukan bersama.

Sedangkan dilihat dari kegunaannya, menurut Kantaprawira (1988:60), komunikasi politik berguna untuk menghubungkan pikiran politik yang hidup dalam masyarakat, baik pikiran intragolongan, institut, asosiasi, ataupun sektor kehidupan politik masyarakat dengan sektor pemerintahan. Rush dan Althoff (1997:24) mengatakan bahwa komunikasi politik memainkan peranan yang amat penting di dalam suatu system politik. Ia merupakan elemen dinamis, dan menjadi bagian yang menentukan dari proses sosialisasi politik, partisipasi politik, dan rekrutmen politik.

Asep Saeful Muhtadi (2008:29) berupaya mengintegrasikan pandangan dari berbagai pakar dengan mengemukakan bahwa komunikasi politik merupakan jembatan untuk menyampaikan pesan-pesan yang dapat memfungsikan kekuasaan. Proses ini berlangsung di semua tingkat masyarakat dan setiap tempat yang memungkinkan terjadinya pertukaran informasi di antara individuindividu dengan kelompok-kelompoknya; bahkan di antara anggota masyarakat dengan para penguasanya.

Dengan demikian, komunikasi politik bermakna sebagai pengerahan segala potensi untuk menyampaikan keinginan kepada manusia untuk mencapai kekuasaan.Kekuasaan sebagai amanah memuliakan sesama manusia, memanfaatkan potensi alam, serta wahana penyembahan kepada kepada Tuhan Yang Maha Esa.Setiap negara atau kesatuan masyarakat tertentu memiliki konsensus untuk mengikat dan mengaktifkan warganya.

\section{Islam dan Politik di Kota Palu}

Sejarah Singkat Kota Palu

Kota Palu sebagai ibukota Provinsi Sulawesi Tengah pada masa pemerintahan kolonial Belanda merupakan sub wilayah 
(onder afdeling) dari Donggala. Sebagai onder afedeling Palu terdiri atas landscap Palu yang meliputi Distrik Palu Timur, Distrik Palu Tengah, dan Distrik Palu Barat.Selain landscap Palu, wilayah onder afdeling juga meliputi landscap Kulawi dan landscap Sigi Dolo.

Cikal bakal Kota Palu terbentuk atas terjadinya pengalihan pusat pemerintahan Kabupaten Donggala dari Banawa ke Palu, pada tahun 1950.Bekas Kantor Bupati Donggala adalah yang kini menjadi Kampus Universitas Alkhairaat Jl. Diponegoro No. 12 Palu.Pengalihan tersebut diprkarsai oleh Ketua Yayasan Alkhairaat yang juga Bendahara Dewan Pimpinan Pusat (DPP) Partai Golkar dengan Bupati Donggala, H. Nabi Bidja pada tahun 2001. Sedangkan Rumah Jabatan Bupati Donggala adalah yang kini menjadi Wisma Donggala Jl. Diponegoro No. 13 Palu.

Berdasarkan Undang-Undang Nomor 44 Tahun 1950, wilayah Sulawesi Tengah berkedudukan di Poso dan Palu menjadi tempat kedudukan kepala pemerintahan negeri setingkat wedana. Kemudian kota teluk ini menjadi ibukota Keresidenan pada tahun 1957. Setelah pembentukan Provinsi Daerah Tingkat I Sulawesi Tengah, Palu menjadi wilayah administratif berdasarkan Peraturan Pemerintah Nomor 18 Tahun 1978.

Perkembangan Palu terjadi pasca penetapan sebagai Kotamadya pada tahun 1994 sekaligus ibukota Provinsi Sulawesi Tengah.Kota ini terletak sekitar $1.650 \mathrm{~km}$ sebelah timur laut Jakarta. Luas wilayah 395,1 km². Penduduknya berjumlah 342.754 jiwa. Kota Palu berada di Teluk Palu, sebelah barat Selat Makassar. Asal usul nama Kota Palu adalah kata Topalu'e yang artinya tanah yang terangkat karena daerah ini awalnya lautan. Peristiwa gempa bumi lalu terjadi pergeseran lempeng (Sesar Palu Koro) sehingga daerah yang tadinya lautan, terangkat dan membentuk daratan lembah yang sekarang menjadi Kota Palu.Daerah otonom ini dibagi kepada 8 kecamatan dan 45 kelurahan. Kecamatan-kecamatan tersebut adalah Palu Barat, Ulujadi, Palu Selatan, Tatanga, Palu Timur, Mantikulore, Palu Utara, dan Tawaeli.

Pemerintahan pada masa lalu, sudah dikenal struktur birokrasi kerajaan yang bernama Kagau.Raja disebut Magau, didampingi oleh Raja Muda yang disebut Madika Magau. Dalam penyelenggaraan 
pemerintahan, Magau dibantu oleh Libu Nu Maradika (Dewan Pemerintahan Kerajaan) yang terdiri atas : Madika Matua (Ketua Dewan Kerajaan/Perdana Menteri) bersama Punggawa (Pengawas Pelaksana Adat/Hubungan Dalam Negeri), Galara (Hakim Adat), Pabisara (Juru Bicara), Tadulako (Urusan Keamanan/Panglima Perang), dan Sabannara (Bendahara dan Urusan Pelabuhan).

Di samping Libu Nu Maradika, ada Libu Nto Dea (Dewan Permusyawaratan Rakyat) yang beranggotakan Pitunggota Ngata (Dewan yang mewakili Tujuh Penjuru Wilayah).Bentuk Kota Pitunggota atau Kota Patanggota berdasarkan luas wilayah kerajaan yang memiliki banyaknya perwakilan Soki (kampung).Ketua Kota Pitunggota atau Kota Patanggota disebut Baligau.

Suku Kaili adalah penduduk asli Kota Palu.Strata sosial masyarakat Kaili mengenal beberapa tingkatan yaitu Madika/ Maradika (golongan keturunan raja atau bangsawan), Totua Nungata (golongan tokoh-tokoh masyarakat), Todea (golongan masyarakat biasa), dan Batua (golongan hamba/budak).

Pada zaman sebelum penjajahan Belanda, daerah yang didiami suku Kaili memiliki raja yang masing-masing menguasai daerah kekuasaan, seperti Banawa, Palu, Tavaeli, Parigi, Sigi, dan Kulavi. Raja-raja tersebut mempunyai pertalian kekeluargaan yang diperkuat oleh tali perkawinan antara satu dengan yang lainnya, dengan maksud untuk mencegah pertempuran antara satu dengan lainnya serta mempererat kekerabatan.

Suku Kaili adalah suku bangsa Indonesia yang secara turun temurun mendiami sebagian besar dari Provinsi Sulawesi Tengah, khususnya wilayah Kabupaten Donggala, Kabupaten Sigi, dan Kota Palu.Kawasan ini berada di lembah antara Gunung Gawalise, Gunung Nokilalaki, Kulawi, dan Gunung Raranggonau.Mereka juga menghuni wilayah pantai timur Sulawesi Tengah, meliputi Kabupaten Parigi Moutong, Kabupaten Tojo Una Una dan Kabupaten Poso. Masyarakat suku Kaili mendiami kampung/desa di Teluk Tomini yaitu Tinombo, Moutong, Parigi Sausu, Ampana, Tojo dan Una Una.Sedang di Kabupaten Poso mereka mendiami daerah Mapane, Uekuli dan pesisir Pantai Poso. 
Sejarah perkembangan pembangunan Kota Palu tidak lepas dari peran sosok pemimpin daerah yang saat ini tercatat telah tujuh kali pergantian kepemipinan kepala daerah.Adapun urutan kepala daerah di Kota Palu, yaitu; Drs. H. Kiesman Abdullah, Walikota Administratif, 1978-1986, Drs. Syahbuddin Labadjo, Walikota Administratif, 19861994.Rully A. Lamadjido, Walikota Administratif, 1994-2000.H. Baso Lamakarate dan Suardin Suaebo, Walikota dan Wakil Walikota Palu, 2000-2004.H. Suardin Suaebo, Walikota Palu, 2004-2005.Kepala Daerah ini melanjutkan masa bhakti satu periode, karena H. Baso Lamakarate meninggal dunia pada 24 Mei 2004.H. Rusdy Mastura dan H. Suardin Suaebo, Walikota dan Wakil Walikota Palu, 2005-2010. Dan H. Rusdy Mastura dan H. Mulhanan Tombolotutu, Walikota dan Wakil Walikota Palu, 2010-2015.

Pada 27 September 2014, Kota Palu merayakan Hari Ulang Tahun (HUT) ke 36, ditandai dengan perkembangan yang sangat pesat. Deretan supermarket berdiri di kota ini dengan segala ativitas bisnisnya, yaitu Matahari, Carrefour, dan Ramayana. Hotel-hotel berbintang juga mengisi kilau gemerlap Teluk Palu, yaitu Swissbell Hotel, Hotel Grand Duta, Mercure Hotel, Hotel Santika, Hotel Sutan Raja, dan Hotel Palu Golden. Denyut nadi pembangunan niaga dikomplekskan oleh kehadiran Kawasan Ekonomi Khusus (KEK) Palu.

\section{Palu Kota Religi}

Penyematan nama Bandar Udara Mutiara SIS Aldjufri di Kota Palu menandakan bahwa penetrasi politik muballig mampu memengaruhi jantung kekuasaan di Kota Palu. Besarnya massa Alkhairaat mendorong Walikota Palu mengusulkan penambahan nama pendiri Perguruan Islam Alkhairaatpada Bandar Udara di ibukota Provinsi Sulawesi Tengah ini. Akumulasi massa terkumpul dalam acara Haul Guru Tua setiap tahun setelah lebaran Idul Fitri, yakni pada setiap tanggal 12 Syawal penanggalan Hijriyah.

Sayyid Idrus bin Salim (SIS) Aldjufri adalah muballig dari Hadramaut Yaman yang mendirikan Perguruan Islam Alkhairaat di Kota Palu. Organisasi ini mengembangkan pendidikan dan dakwah di kawasan timur Indonesia. Sehubungan dengan berdirinya cabangcabang organisasi di berbagai daerah, dibentuklah Pengurus Besar 
Alkhairaat. Ini artinya bahwa Alkhairaat sudah menjadi organisasi massa (ormas). SIS Aldjufri berhasil melakukan transformasi sosial pada proses pengembangan dakwah di Kota Palu yang merambah pulau Maluku, Sofifi, Ternate, Papua, dan Kalimantan.

Kini Alkhairaat menjadi primadona politisi dari berbagai macam partai untuk mendekatinya, karena dianggap memiliki pengaruh potensial elektabilitas. Calon presiden, calon wakil presiden, dan politisi nasional lainnya selalu mengagendakan untuk bertemu dengan pimpinan Alkhairaat, ketika mengunjungi Kota Palu. Pada 11 Juni 2014 misalnya, Calon Wakil Presiden H.M. Jusuf Kalla mengunjungi dan bertemu dengan Ketua Utama Alkhairaat, Sayyid Saggaf Muhammad Aldjufri.Setiap menjelang event politik, seperti Pemilihan Umum Legislatif, Pemilihan Presiden, dan Pemilihan Kepala Daerah, pimpinan Alkhairaat selalu didatangi untuk minta restu dalam rangka peluang keterpilihan seorang kandidat.

Wilayah markas Perguruan Alkhairaat ditetapkan sebagai Kawasan Kota Religi oleh Walikota Palu, H. Rusdy Mastura pada tahun 2008.Kawasan ini meliputiwilayah Palu Barat, dengan konsentrasi Kelurahan Baru, Kelurahan Kamonji, Kelurahan Siranindi, Kelurahan Boyaoge, dan Kelurahan Lere. Prakarsa ini tidak terlepas dari jejak dakwah Pendiri Utama Alkhairaat, Sayyid Idrus bin Salim Aldjufri. Perguruan Alkhairaat di kawasan ini terdiri atas unit perkantoran, unit pendidikan, dan unit usaha.

Untuk unitperkantoran Alkhairaat, yaitu; Kantor Pengurus Pusat Alkhairaat, Kantor Yayasan Alkhairaat, Kantor Badan Pengurus Harian Yayasan Alkhairaat, Kantor Pengurus Pusat Wanita Islam Alkhairaat (WIA), Kantor Pengurus Pusat Himpunan Pemuda Alkhairaat (HPA), Kantor Pengurus Pusat Banaat Alkhairaat, Kantor Pengurus Pusat Ikatan Alumni Alkhairaat(IKAAL). Sementara untuk unit pendidikan Alkhairaat, yaitu; Universitas Alkhaairaat, Madrasah Aliyah Alkhairaat, Sekolah Menengah Kejuruan (SMK) Alkhairaat, Madrasah Tsanawiyah (MTs) Alkhairaat, Sekolah Menengah Pertama (SMP) Alkhairaat, Sekolah Dasar (SD) Alkhairaat, Taman Kanak-Kanak (TK) Alkhairaat. Sedangkan unit usaha Alkhairaat, yaitu; Rumah Sakit Alkhairaat, Swalayan Alkhairaat, dan Kawasan Ekonomi Khusus Alkhairaat (KEKAL). 
Islam masuk di Tanah Kaili yang termasuk Kota Palu merupakan rangkaian penyebaran Islam di Kerajaan Bone (kini Kabupaten Bone Provinsi Sulawesi Selatan).Raja Bone menerima Islam dari Raja Gowa. Pengaruh ajaran Islam di Kerajaan Gowa mendorong terjadinya persekutuan dengan Kerajaan Tallo, yang kemudian dikenal dengan nama Kerajaan Makassar. Raja Bone yang mencurigai adanya ideologisasi politik Islam mendorong pula melakukan traktat perjanjian dengan kerajaan tetangga yaitu Kerajaan Soppeng dan Kerajaan Wajo, yang terkenal dengan nama persektuan Tellumpoccoe. Ketiga kawasan itu disingkat menjadi BOSOWA (Bone Soppeng Wajo).

Kini BOSOWA sudah menjelma menjadi kerajaan bisnis jaringan Kalla Group yang menguasai pangsa pasar di kawasan timur Indonesia.Kalau dulu, serangan Tellumpoccoe yang dimotori oleh Raja Bone Arung Palakka berhasil menaklukkan Kerajaan Makassar berkat bantuan Batavia (Betawi - Jakarta). Sekarang, BOSOWA berhasil menjelajahi daerah-daerah bekas kekuasaan Kerajaan Makassar, dengan bendera bisnis, sosial dan budaya.Ini didukung oleh pusat kekuasaan Republik Indonesia (Jakarta), dengan tampilnya H.M. Jusuf Kalla dari Bone sebagai Wakil Presiden Republik Indonesia. Kalau dulu takluknya Makassar ditandai dengan Perjanjian Bongaya, kini dengan perambahan properti Tanjung Bunga.

Muballig politisi di Kota Palu didominasi oleh orang-orang Bugis yang nenek moyangnya sudah lebih dulu melakukan penetrasi budaya di Tanah Kaili. Marga-marga keluarga Madika di Tanah Kaili yang berasal dari Tanah Bugis yaitu Lamajido, Lamakampali, Lamakarate, Tombolotutu, Pettalolo, Potabuga, Lapasere, Lamarauna, Parampasi, dan lain-lain. Kemampuan penetrasi budaya orang-orang Bugis di Kota Palu, diawali dengan kegiatan bisnis lalu menata dan meniti peluang di partai politik.

Nisbah (2012:13) mengemukakan bahwa pada masyarakat Kaili, penggolongan orang-orang sekerabat dapat diidentifikasi berdasarkan nama besar yang dikenali melalui identitas ayah. Pembentukan klan dengan menggunakan marga dapat menunjukkan identitas seseorang dalam masyarakat Kaili di Lembah Palu. Ikatan genealogi pada satuan klan sering menjadi dasar pengelompokan anggota-anggota dalam kelembagaan politik. 
Kehadiran partai sebagai saluran resmi aspirasi dan partisipasi politik dimaknai oleh muballig di Kota Palu sebagai sebagai sarana ibadah untuk memuluskan kegiatan dakwah. Keberhasilan dukungan politik muballig untuk duduk di parlemen, mendorong terjadinya perluasan areal dakwah. Muballig di parlemen memiliki kesempatan untuk menasehati Walikota dan para Kepala Dinas dalam mengembang amanah masyarakat Kota Palu.

Semangat kedakwahan politik di Kota Palu, ditunjukkan oleh Walikota dengan program Peduli Du'afa (afirmasi program kerja birokrasi untuk mengentaskan kemiskinan) pada tahun 2005 - 2010, periode pertama kepemimpinan Walikota Palu Rusdi Mastura. Pada periode kedua $(2010$ - 2015) kegiatan itu bernama Zero Poverty. Penamaan ini dipenagrahi oleh seringnya Walikota melancong (studi banding) keluar negeri seperti Swiss, Swedia, dan negara Eropa lainnya. Namun, masyarakat miskin kota tidak terpengaruh dengan perubahan istilah dari bahasa Arab ke bahasa Inggris, yang penting "bisa makan".

\section{Metodologi Penelitian}

Penelitian ini menggunakan pendekatan fenomenologi. Fenomena adalah hal yang tampak sebagai sebuah dinamika kehidupan, sedangkan di balik yang tampak itu ada peristiwa yang disebut nomena.Dinamika komunikasi politik muballig merupakan fenomena sosial yang dilatarbelakangi oleh nomena kepentingan dakwah dan kepentingan lainnya. Muballig "juga manusia" yang ingin tampil dalam aktualisasi diri melalui aksentuasi penampilan dakwah.

Penerapan fenomenologi dalam penelitian dikemukakan oleh beberapa pakar.Fenomenologi lebih banyak dijalankan pada tingkat metasosiologis, dengan menunjukkan premis-premisnya melalui analis deskriptif dari prosedur situasional dan bangunan sosialnya (Myron Orleans, 2002: 32). Fenomenologi akan berusaha memahami pemahaman informan terhadap fenomena yang muncul dalam kesadarannya, serta fenomena yang dialami oleh informan dan dianggap sebagai entitas sesuatu yang ada dalam dunia (Finn Collin, 1997: 115). 
Ideologimuballigsudahtertanam sejakawalberinteraksidengan kelompok atau organisasi yang menaungi dan membelajarkannya. Perbedaan mazhab dalam Islam juga berdampak pada sendi-sendi realitas sosial. Lahirnya lembaga-lembaga dakwah disebabkan oleh perbedaan pandangan mazhab seseorang atau kelompok dengan yang lainnya. Muballig yang bergabung sebagai anggota atau pengurus di lembaga dakwah tertentu, selalu menyampaikan ideologi dakwah institusional.

Dukungan lembaga dakwah terhadap pasangan kandidat presiden dan wakil presiden mendorong muballig untuk menyampaikan pesan politik berdasarkan pilihan organisasi. Muballig sebagai informan penelitian, ditampilkan pandangannya berdasarkan fenomena yang muncul ketika menyampaikan dakwah. Alasan-alasan politis memang menjadi wajar, karena muballig berada di arena diplomatika sosial.

Penelitian ini berlangsung dari 4 Juni 2014 sampai dengan 5 Juli 2014, berdasarkan Keputusan Komisi Pemilhan Umum, Nomor 457/Kpts/KPU/Tahun 2014, tentang Jadual Kampanye Rapat Umum Dalam Pemilihan Umum Presiden dan Wakil Presiden Tahun 2014. Selama masa kampanye, peneliti melakukan observasi terhadap kegiatan-kegiatan dakwah, yakni Khutbah Jum'at, Pengajian Majelis Taklim, Peringatan Isra dan Mi'raj, Takziyah, dan Ceramah Ramadhan. Pada kegiatan keagamaan ini, penulis mengobservasi pesan-pesan politik yang terselip pada ceramah agama.Demikian pula pada kegiatan kampanye Tim Sukses Probowo - Hatta dan Tim Sukses Joko Widodo - Jusuf Kalla, penulis mengobservasi penampilan muballig yang menjadi anggota Tim Sukses.

Muballig dakwah dan muballig politikus yang tampil di arena kampanye, selanjutnya diwawancarai oleh peneliti tentang aktivitas dakwah politik selama masa kampanye berlangsung. Hal ini dilakukan oleh peneliti, karena tidak semua kegiatan dakwah dan politik dapat diobservasi oleh peneliti.Kegiatan wawancara juga berfungsi sebagai sarana konfirmasi terhadap visi dan mis calon presiden dan wakil presiden. Wawancara juga dapat mengungkapkan peran muballig politikus dalam Tim Sukses dan muballig dakwah yang merupakan simpatisan calon presiden dan calon wakil presiden. 


\section{Hasil Penelitian}

Azyumardi Azra (2014 : 6) mengemukakan bahwa dalam konteks penggunaan simbol-simbol keagamaan, orang dapat menyaksikan perbedaan di antara kedua pasangan calon Presiden dan calon Wakil Presiden dalam deklarasi resmi masing-masing pada 19 Mei 2014. Deklarasi pasangan Jokowi - JK terlihat tidak menampilkan nuansa Islam secara spesifil kecuali dengan penggunaan salam khas "assalau alaikum" ketika Jokwi memberikan sambutan singkat. Sebaliknya, deklarasi pasangan Prabowo - Hatta dimulai dengan bacaan ayat-ayat Al-Qur'an tentang umat Islamagar tidak bercerai berai atau bersatu. Selain itu, hamper sepanjang acara deklarasi pasangan ini diwarnai teriakan takbir Allahu Akbar. Dengan demikian, simbolisme Islam terlihat begitu menonjol dalam deklarasi pasangan Prabowo - Hatta.

Pandangan tersebut juga terjadi di Kota Palu.Selama kegiatan kampanye berlangsung, Tim Sukses kubu Prabowo - Hatta sering melakukan kegiatan keagamaan. A.J. Wartabone, politisi Partai Golkar yang juga anggota DPRD Kota Palu, melaksanakan kegiatan keagamaan, dengan menggunakan organisasi massa yang dibentuknya, yaitu Indonesia Berzikir. Sasaran pembinaan Indonesia Berzikir adalah majelis-majelis taklim di Kota Palu. Majelis Taklim adalah organisasi perkumpulan para ibu, dalam rangka mempelajari agama Islam.Majelis Taklim binaan Indonesia Berzikir menjadi modal politik yang mengantarkan A.J. Wartabone menjadi calon terpilih anggota DPRD Kota Palu periode 2014 - 2019.

Sehubungan dengan dukungan Partai Golkar kepada Calon Presiden dan Wakil Presiden Prabowo - Hatta, Indonesia Berzikir kembali menggalang kekuatan massa di kalangan Majelis Taklim Kota Palu. Poros Muslimah Sulawesi Tengah yang dibina oleh Zalzulmida Djanggola, calon terpilih anggota DPRD Provinsi Sulawesi Tengah periode 2014 - 2019 dari Partai Gerindra, juga berkolaborasi dengan Indonesia Berzikir mendukung Prabowo - Hatta. Kolaborasi bertambah semarak karena mendapatkan dukungan dari Syarifah Sa'diyah Aldjufrie, Ketua Umum Wanita Islam Alkhairaat (WIA). Poros Muslimah Sulawesi Tengah dipimpin oleh Syarifah Balgis Alkadri dideklarasikan pada 4 Juni 2014 dalam rangka mendukung Prabowo - Hatta. 
Muballig yang tergabung dalam Partai Keadilan Sejahtera, menunjukkan sikap "sami'na wa ata'na" (ketaatan mutlak) sebagai kader partai dalam menyukseskan dukungan politik.Mohammad Ali Lamu, anggota Dewan Perwakilan Rakyat Daerah (DPRD) Kota Palu tetap mengikuti instruksi partai untuk mendukung Prabowo - Hatta Rajasa. Murabbi PKS ini selalu menunjukkan loyalitas partai, karena menganggap bahwa manfaat ketaatan lebih besar dari manifesto mendukung kandidat lainnya walaupun memiliki kekerabatan. Hal ini pula ditunjukkan oleh Presiden PKS, Anis Matta yang sekampung dengan H.M. Jusuf Kalla dari Kabupaten Bone, namun tetap loyalitas mendukung calon presiden nomor 1, karena sudah menjadi keputusan partai.

Muhammad Yusuf Khalid, salah seorang muballig di Kota Palu, direkrut menjadi Juru Kampanye Pasangan Calon Nomor 1. Posisinya sebagai anggota Partai Amanat Nasional (PAN) Kota Palu, juga mengikuti perintah Dewan Pimpinan Pusat (DPP) PAN. Kegiatan dakwah politik diawali pada acara GEMPAR (Gerakan Massa Pemenangan Prabowo) di kantor DPD I Partai Golongan Karya, 3 Juni 2014. Taushiah politik disampaikan oleh Ust.Rizal dari Partai Keadilan Sejahtera.

Selama musim kampanye 4 Juni - 5 Juli 2014, Muhammad Yusuf Khalid tampil sebagai delapan kali membawa pesan-pesan pemenangan Prabowo - Hatta.Kegiatan dakwah yang dimanfaatkan adalah Takziyah. Takziyah adalah upacara ritual keagamaan dalam rangka mengenang orang-orang yang sudah meninggal dunia.'Tradisi di Kota Palu, Takziyah dilaksanakan pada hari pertama setelah pemakaman berlangsung. Berturut-turut ritual keramaian selama tiga malam.Setiap malam, panitia Takziyah selalu menampilkan muballig untuk memberikan taushiyah berupa nasehat kepada keluarga yang ditinggalkan untuk bersabar. Pada kesempatan tersebut, sang muballig menyelipkan pesan-pesan politik untuk keterpilihan kandidat tertentu. Terdapat juga dalam peringatan Isra Mi'raj Nabi Muhammad SAW. Teknik dakwah politik tidak diungkapkan secara eksplisit, tapi secara implisit. Kalimat yang diselipkan di antara pesan-pesan dakwah,Muhammad Yusuf Khalid, pada ceramah Isra dan Mi'raj pada tanggal 6 Juli 2014, yaitu; 
Bahwa Indonesia masih membutuhkan pemimpin yang tegas dalam rangka menghadapi kondisi masyarakat yang masih sering diwarnai konflik antar antar kelompok.Demikian pula aksi premanisme yang merajalela dan pemberantasan korupsi, membutuhkan pemimpin yang bisa memimpin, bukan pemimpin yang dipimpin. Tipe pemimpin demikian hanya bisa didapatkan dari kalangan militer.

Walaupun nama kandidat tidak disebutkan, namun peserta dakwah dapat memahami isi pesan dakwah. Satu-satunya calon presiden yang berasal dari militer yaitu Probowo Subianto.Strategi ini dilakukan untuk menghindari jeratan hukum pidana pemilihan umum, yaitu larangan kampanye pada kegiatan keagamaan.Badan Pengawas Pemilu (Bawaslu) tampil dengan ketat mengawasi jalannya kampanye, dengan tegas membubarkan kegiatan kampanye yang menyalahi prosedur.

Pemanfaatan telepon seluler, juga tidak luput dalam dipergunakan oleh kubu Prabowo - Hatta.Nomor telepon seluler 08234724xxxx, milik politisi salah satu partai pendukung Prabowo - Hatta, mengirim pesan ke telepon seluler penulis, yaitu :

As wr wb, ini bunyi BBM (Blackberry Massenger) Ahok kpd kelompok CINA + KRISTEN:

1. Teman seiman yang dikasihi Tuhan Yesus, mari kita rptkan barisan menjaga kekristenan kita dengan memilih PDIP/ Hanura.

2. Kuasa Salib sdh di dpn mata. Kasih Yesus dan kuasa Gereja akan terbukti setelah 9-7-2014

3. PILPRES: Satukan barisan utk JOKOWI, setelah Jokowi jadi Presiden, Ahok pasti jadi Gubernur dan kuasa Yesus akan hadir di Jakarta untuk kalahkan .............

4. Jangan kuatir, hatinya Jokowi seiman dengan kita.

5. Kristen harus kuasai Jakarta. Kalbar dan Kalsel sdh di tangan qta. Kristen akan berkibar di NKRI dari Sabang sp Merauke. 
NB: Hai ... Sdrku sesama Muslim, semoga hal ini menjadi perhatian kita dan qt harus tau siapa yang akan qt pilih sbg pemimpin qt, dan perlu ingat jika Jokowi jd Presiden maka Ahok jadi Gubernur Jakarta, itu berarti saudara kita di Jakarta, kita biarkan dipimpin orang Kristen, bahkan kitalah penyebabnya. BANTU SEBARKAN KEPADA SAUDARA KITA YANG MUSLIM.

Pengirim:

$+628234724 \mathrm{xxxx}$

Pusat pesan: +6281100000

Dikirim: 24 Mei 2014, 10:10:37

Pesan singkat yang disampaikan oleh salah satu kader partai pendukung calon Presiden dan calon Wakil Presiden, mengarahkan untuk memilih Prabowo - Hatta.Pesan kampanye yang disampaikan memanfaatkan fanatisme keberagamaan. Penduduk Indonesia mayoritas muslim didekati dengan melancarkan simbol-simbol keyakinan.

Penggunaan telepon seluler untuk kampanye juga disampaikan oleh seorang kader Partai Gerindra, NS, tanggal 23 Juni 2014dengan pesan singkat sebagai berikut:

Renungkan ...!!

Subhanallah. Dgn Ridha Allah kelebihan nama PRABOWO. Dari hitungan angka huruf. Abjad P : 16, R : 18, A : 1, B : 2, O : 15, W : 23, O : 15 Total : 90. Buka Al-Qur'an Surah ke 90 adalah Al-Balad. Intinya masalah negeri ini yang aman dan makmur, tidak menemui kesukaran, membebaskan budak, menyantuni anak yatim dan orang-orang susah, bersabar dan berkasih sayang. Kelebihan lain Pemilu akan dilaksanakan tanggal 9 bulan 7 dijumlahkan jadi 16 ditambah nomor urut 1 menjadi 9+7+1=17. Pemilu tepat bulan puasa Ramadhan.

\section{Renungkan ...!!}

Turunnya Al-Qur'an sebagai pedoman hidup tgl 17 Ramadhan dan Indonesia merdeka bebas dari penjajah tgl 17 Agustus. Semoga Allah titipkan PRABOWO menjadi Presiden Negara RI ini ke depan. Amin Ya Allah. 
Penggunaan sembol-simbol angka menurut Al-Qur'an dijadikan bahan kampanye, untuk menggugah emosional keagamaan umat Islam.Produksi pesan-pesan keagamaan politik Tim Sukses Prabowo - Hatta, dimotori oleh para muballig yang dengan tidak sengaja tiba-tiba mendapatkan inspirasi "rahmat" sehingga tercipta angka-angka klenik untuk pasangan Nomor 1. Berbarengan pula, Pemilihan Umum Presiden dan Wakil Presiden pada bulan Ramadhan.'Tanggal 9 Juli 2014 bertepatan 11 Ramadhan 1435 Hijriyah.

Lain halnya anggota Partai Persatuan Pembangunan (PPP), Abdul Rahman Taha yang mendukung Jokowi-H.M. Jusuf Kalla, padahal keputusan Dewan Pimpinan Pusat PPP mendukung Prabowo-Hatta Rajasa.Keputusan "anak guru mengaji” ini didasarkan bahwa kemampuan manajerial pemerintahan H.M. Jusuf Kalla sudah teruji selama menduduki jabatan-jabatan di pemerintahan.Demikian pula, Jokowi terkenal bersih dan sederhana sehingga dianggap mampu membawa negara kea rah yang lebih baik.

Partai-partai di Indonesia terbagi atas dua macam asas ideologis, yaitu partai religius nasional(PPP, PKS, PKB, PAN, dan PBB) dan partai nasional religius(Partai Golkar, PDIP, Partai Demokrat, Partai Gerindra, Partai Hanura, Partai Nasdem, dan PKPI).Partai religius nasional didirikan oleh sejumlah orang dengan latar belakang muballig atau aktivis lembaga-lembaga keagamaan Islam, yang kemudian dikenal dengan lembaga dakwah. Kepengurusan partai didominasi oleh para muballig yang kemudian mewarnai pesan-pesan dakwahnya berdasarkan keputusan partai. Dalam kondisi kampanye pemilihan presiden dan wakil presiden, para muballig dari partai-partai religius nasional sering menyelipkan pesan-pesan politik pada setiap kesempatan dakwahnya.

Demikian pula partai berbasis nasional berupaya melekatkan kata "religius", sehingga dikenal "partai nasional religius". Untuk melembagakan religiusitas itu, partai-partai ini mendirikan sayap organisasi yang bergerak di bidang dakwah.Partai Golkar, sejak Orde Baru membentuk Majelis Dakwah Islamiyah (MDI), Gabungan Usaha Perbaikan Pendidikan Islam (GUPPI), Angkatan Muda 
Islam Indonesia (AMII), dan Sekretaris Jenderal Idrus Marham pernah memimpin Badan Komunikasi Pemuda Remaja Masjid Indonesia (BKPRMI). PDIP membentuk Baitul Muslimin Indonesia (BAMUSI).Partai Gerindra membentuk Gemira (Gerakan Muslim Indonesia Raya).

Sayap-sayap politik partai ikut semarak dalam kegiatan kampanye Pemilihan Presiden dan Wakil Presiden RI.Penetrasi dakwah dilaksanakan dengan intensitas tinggi seperti majelis taklim, pengajian, halaqah dan tarbiyah.Muballig non kader partai yang diundang menyampaikan ceramah pada kegiatan dakwah politik, tentu sudah paham maksud acara tersebut.Muballig tentu memberikan pencerahan tentang politik Islam yang mendukung keinginan pihak pengundang (shohibul hajat).

\section{Pemberdayaan Muballig di Kota Palu}

Peranan birokrasi terhadap pemberdayaan muballig di Kota Palu tampak pada pendanaan lembaga-lembaga dakwah yang dibiayai melalui APBD (Anggaran Pendapatan dan Belanja Daerah), baik Pemerintah Kota Palu maupun Pemerintah Provinsi Sulawesi Tengah. Perlakuan Pemerintah Provinsi terhadap lembaga-lembaga dakwah di Kota Palu menjadi prioritas karena kota ini sebagai ibukota Provinsi Sulawesi Tengah.

Muballig yang berada di sebuah lembaga dakwah di Kota Palu, akan selalu diikutkan pada kegiatan pelatihan dai, pengkaderan ulama, safari Ramadhan, dan pemberian santunan melalui Badan Amil Zakat atau Bagian Kesejahteraan Rakyat (Kesra). Majelis Ulama Indonesia (MUI) Provinsi Sulawesi Tengah sebagai induk organisasi lembagalembaga dakwah, selalu melakukan pendekatan kepada Gubernur Sulawesi Tengah dalam kegiatan pemberdayaan muballig.

Pada kampanye Pemilihan Presiden dan Wakil Presiden, MUI Provinsi Sulawesi Tengah menghadapi kegamangan, karena Tim Sukses Jokowi JK menawarkan ajakan kampanye pada pasangan nomor 2.Tim Jokowi JK menawarkan sarana transportasi yang sudah dibranding Jokowi JK dan sejumlah insentif selama berlangsungnya kampanye presiden.Organisasi MUI memiliki daya tarik bagi 
kandidat karena organisasi ini memiliki reputasi yang bagus di mata masyarakat, terutama dengan label halal pada makanan, minuman, dan kosmetik.

Tawaran tersebut ditolak oleh pengurus MUI karena Gubernur Sulawesi Tengah, H. Longki Djanggola berasal dari Partai Gerindra penyokong pasangan Prabowo Hatta. Pada kondisi ini, MUI berhasil menunjukkan posisi netral dalam even politik di mata masyarakat Kota Palu.

Beberapa pengurus MUI yang juga muballig di Kota Palu mengemukakan pandangannya terhadap tawaran-tawaran politik, sebagai rizqun minallah.MUI yang tidak berafiliasi pada partai politik tertentu, memiliki personil muballig dari berbagai lembaga dakwah di Kota Palu. Lembaga-lembaga dakwah penyokong MUI yaitu Alkhairaat, Muhammadiyah, Nahdlatul Ulama, As'adiyah, Darul Dakwah Wal Irsyad (DDI), Wahdah Islamiyah, Hizbut Tahrir Indonesia, Jama'ah Tablig, Persatuan Islam (Persis), Dewan Dakwah Islam Indonesia (DDII), Hidayatullah, dan lain-lain.

Keterlibatan muballig non partai dalam Tim Sukses Kampanye Calon Presiden dan Wakil Presiden, ditempuh pada dua jalur. Pertama, perekrutan lembaga dakwah. Kedua perekrutan individual. Lembaga dakwah yang menerima tawaran kampanye dari Tim Sukses, langsung melibatkan muballig untuk menyampaikan pesanpesan politik kepada masyarakat.Sedangkan perekrutan individual, terletak pada figur muballig yang memiliki reputasi dan popularitas di masyarakat.

\section{Kesimpulan}

Berdasarkan hasil penelitian tentang Komunikasi Politik Muballig di Kota Palu (Studi Kampanye Pemilihan Presiden dan Wakil Presiden Republik Indonesia Tahun 2014), dapat dikemukakan kesimpulan, bahwa negosiasi yang dilakukan oleh muballig di Kota Palu untuk tampil menyampaikan kampanye, yakni dengan (a) menjadi anggota tim kampanye salah satu pasangan kandidat bagi muballig yang menjadi anggota partai peserta pemilihan umum, (b) menyisipkan pesan-pesan politik untuk keterpilihan salah satu kandidat, bagi muballig yang menaruh simpatik kepada salah satu pasangan kandidat. 
Konsolidasi politik yang dilakukan oleh muballigdengan (a) membangun komunikasi dengan sesame pengurus partai, bagi muballig yang menjadi anggota partai peserta pemilihan umum, (b) memperkuat soliditas hubungan emosional etnis bagi muballig simpatisan salah satu pasangan kandidat.

Pencitraan politik yang dilakukan oleh muballig terhadap kedua calon presiden dan calon wakil presiden dilakukan secara tampak (eksplisit) bagi muballig politikus dan pencitraan dilakukan secara sentilan (implisit) bagi muballig dakwah.

\section{Daftar Pustaka}

Azra, Azyumardi. 2014. Simbolisme Islam dan Pilpres.Jakarta: PT Kompas Gramedia.

Cangara, Hafied. 2009.Komunikasi Politik; Konsep, Teori, dan Strategi.Jakarta: Rajawali Pers.

Collin, Finn. 1997.Social Reality. USA: Routledge Simultaneously Published.

Orleans, Myron, dalam Basrowi dan Sukidin. 2002.Metode Penelitian Kualitatif Perspektif Mikro. Surabaya: Insan Cendekia.

Kantaprawira, Rusadi. 1988.Sistem Politik Indonesia: Suatu Model Pengantar. Bandung: Sinar Baru.

Muhtadi, Asep Saeful. 2008. Komunikasi Politik Indonesia. Bandung: Remaja Rosdakarya.

Nisbah.2012.Partisipasi Politik Perempuan di Tanah Kaili.Bandung: Program Pascasarjana.

Rush dan Althoff. 1997.Pengantar Sosiologi Politik. Jakarta: Rajawali Press.

Susanto, Astrid S. 1985. Komunikasi Sosial di Indonesia. Bandung: Bina Cipta. 